\title{
Limitations of PCR detection of filarial DNA in human stools from subjects non-infected with soil-transmitted helminths
}

\author{
Maxime P. M. Doret ${ }^{1}$, Hugues C. Nana-Djeunga ${ }^{2}$, Narcisse Nzune-Toche ${ }^{2}$, Sébastien D. S. Pion ${ }^{1}$, Cédric B. Chesnais ${ }^{1}$, \\ Michel Boussinesq ${ }^{1}$, Joseph Kamgno ${ }^{2,3}$, Emmanuelle Varlet-Marie ${ }^{4}$, and Sabrina Locatelli ${ }^{1, a, *}$ \\ ${ }^{1}$ Institut de Recherche pour le Développement (IRD), UMI 233-INSERM U1175-University of Montpellier, 34394 Montpellier Cedex 5, \\ France \\ ${ }^{2}$ Centre for Research on Filariasis and Other Tropical Diseases (CRFilMT), PO Box 5797 Yaoundé, Cameroon \\ ${ }^{3}$ Department of Public Health, Faculty of Medicine and Biomedical Sciences (FMBS), PO Box 1364 Yaoundé, Cameroon \\ ${ }^{4}$ Department of Parasitology-Mycology, Centre Hospitalier Universitaire (CHU) of Montpellier, University of Montpellier, 34295 \\ Montpellier Cedex 5, France
}

Received 15 December 2020, Accepted 11 May 2021, Published online 27 May 2021

\begin{abstract}
The standard techniques for diagnosis of human filariasis are the microscopic examination of blood smears or skin biopsies, which are relatively invasive and poorly sensitive at low levels of infection. Recently, filarial DNA has been detected in fecal samples from non-human primates in Central Africa. The aim of this study was to demonstrate proof-of-concept of a non-invasive molecular diagnosis technique for human filariasis by targeting fragments of $12 \mathrm{~S}$ rDNA, Cox1, ITS1 and LL20-15kDa ladder antigen-gene by conventional PCR in DNA extracted from stool samples of 52 people infected with Mansonella perstans and/or Loa loa. Of these, 10 patients were infected with soil-transmitted helminths (Trichuris trichiura and/or Ascaris lumbricoides), and none were positive for Necator americanus. Interestingly, no filarial gene fragments were detected in the stools of any of the 52 patients. Future studies should evaluate whether a co-infection with soil-transmitted helminths causing gastrointestinal bleeding and likely allowing (micro)filaria exit into the digestive tract, may facilitate the molecular detection of filarial DNA fragments in stool samples.
\end{abstract}

Key words: Mansonella perstans, Loa loa, Stool sample, PCR, Cameroon.

Résumé - Limites de la détection par PCR d'ADN de filaires dans les selles humaines de sujets non-infectés par les géohelminthes. Les techniques standards de diagnostic des filarioses humaines (examen microscopique de gouttes épaisses ou de biopsies cutanées) sont relativement invasives et peu sensibles à de faibles niveaux d'infection. De l'ADN de filaires a été récemment détecté dans des échantillons de fèces de primates non-humains en Afrique centrale. L'objectif de cette étude était de démontrer la preuve de concept d'un diagnostic moléculaire non invasif des filarioses chez l'homme en ciblant des fragments d'ADNr 12S, Cox1, ITS1 et l'antigène LL20-15kDa par PCR classique. L'ADN a été extrait d'échantillons de selles de 52 personnes infectées par Mansonella perstans et/ou Loa loa. Parmi ces patients, dix étaient infectés par des géohelminthes (Trichuris trichiura et/ou Ascaris lumbricoides) et aucun n'était positif pour Necator americanus. De manière intéressante, aucun fragment de gène de filaires n'a été détecté dans les selles des 52 patients. Des études futures devraient être menées pour évaluer si une coinfection avec des géohelminthes (provoquant des hémorragies gastro-intestinales et permettant probablement l'effraction de (micro)filaires dans le tube digestif) facilite la détection moléculaire de fragments d'ADN de filaires dans les selles.

\section{Introduction}

Filariases are vector-borne infections caused by nematode parasites. Adults of the main species infecting humans live in subcutaneous or deep nodules (Onchocerca volvulus), in fascia

*Corresponding author: sabrina. locatelli@ird. fr ${ }^{a}$ Current address: Institut de Recherche pour le Développement (IRD), Maladies Infectieuses et vecteurs: Ecologie, génétique, Evolution et Contrôle (MIVEGEC) (IRD 224 - CNRS 5290 University of Montpellier), Montpellier, France. layers (Loa loa), in the lymphatic circulation (lymphatic filariae), or in body cavities (Mansonella perstans, M. ozzardi). Female worms produce embryos called microfilariae (mf) that migrate into the dermis (O. volvulus) or into the bloodstream (L. loa, lymphatic filariae, M. perstans). Diagnosis relies on the detection of $\mathrm{mf}$ in skin biopsies for onchocerciasis or in a calibrated thick blood smear (CTBS) for the other filariases. These techniques are relatively invasive, and their sensitivity decreases with lower infection intensity. Methods using a molecular approach, like polymerase chain reaction (PCR) [5] 
and loop-mediated isothermal amplification (LAMP) [10, 12], are more specific and sensitive. Recently, Mansonella sp. DNA was detected in fecal samples from non-human primates (NHP) [6]. This study aimed to demonstrate the proof-of-concept of non-invasive diagnosis of human filariasis in stool samples using a conventional PCR method, and to determine whether filarial DNA detection is associated with co-infections with soil-transmitted helminths (STH) causing blood loss while feeding on the host intestinal mucosa.

\section{Materials and methods Ethics guidelines}

The study, conducted in Cameroon, was approved by the Centre Regional Ethics Committee for Human Health Research (No. 00837/CRERSCH/2019). All volunteers were informed one week before the beginning of the study and signed a consent form prior to enrollment.

\section{Study site, samples collection and microscopic analyses}

The subjects included in this study (aged 13-88 years) participated in a project conducted in 2015 in 92 villages of the Okola Health District (Centre Region) to evaluate the efficacy of a rapid diagnostic tool called LoaScope to identify subjects with high L. loa microfilarial densities (MFD) [9]. During this "Test-and-not-Treat" (TaNT) project, individuals with $\geq 20,000$ L. loa $\mathrm{mf} / \mathrm{mL}$ of blood, who were at risk of developing a serious reaction after ivermectin treatment, did not receive the drug. In 2018, 52 of these excluded individuals with high L. loa and/or $M$. perstans MFD participated in the present study. During the information phase of the study, patients were provided with a $60 \mathrm{~mL}$ vial for stool collection and were instructed to hand it with fresh stool (produced the morning of the visit) to the field team the day of the capillary blood collection. Capillary blood samples were collected between 10 am and 4 pm (time of highest L. loa MFD in the peripheral circulation). Loa loa and $M$. perstans MFD were measured by CTBS. Upon receipt of the stool sample, $2 \mathrm{~mL}$ (about $1 \mathrm{~g}$ of stool) were put in a $15 \mathrm{~mL}$ tube and $2 \mathrm{~mL}$ of RNAlater ${ }^{B}$ (Ambion, Austin, TX, USA) were added. Both tubes were transferred to the CRFilMT laboratory in Yaoundé in a cooler with icepacks. The samples in RNAlater ${ }^{\circledR}$ were stored at $-20^{\circ} \mathrm{C}$ for further molecular analyses. For the intestinal parasite eggs counts, Kato-Katz analyses were performed the day after collection on a small amount of stool (41.7 mg template) taken directly from the $60 \mathrm{~mL}$ tube, after homogenization. The remaining stool material was resuspended in formalin for the additional detection of gastrointestinal parasites using the Mini-FLOTAC technique.

\section{DNA extraction}

Fecal DNA was extracted using a QIAamp Fast Stool DNA Mini kit (Qiagen, Valencia, CA, USA), following the manufacturer's instructions. Briefly, $1.5 \mathrm{~mL}$ of fecal-RNAlater ${ }^{\circledR}$ mixture was re-suspended in stool lysis buffer and clarified by centrifugation. The supernatants were treated with an InhibitEx buffer, subjected to proteinase $\mathrm{K}$ digestion, and passed through a DNA binding column. Bound DNA was eluted in $100 \mu \mathrm{L}$ elution buffer. To investigate the presence of gastro-intestinal parasites, a modified DNA extraction protocol was adopted, after the clarification. This step consisted of additional homogenization in tubes containing silica beads of different size (lysis matrix E) in a FastPrep-24 mill (MP Biomedical, Eschwege, Germany) and overnight incubation at $56{ }^{\circ} \mathrm{C}$ to better expose the parasite DNA in eggs. Dried blood spots (DBS) from 20 additional pharmacologically untreated individuals with high MFD (10 infected with $L$. loa only (110,360-269,520 mf/mL) and 10 with $M$. perstans only (960-4020 mf/mL)) enrolled in the project mentioned above were selected as positive controls, and DNA extraction was performed using a NucliSENS ${ }^{\circledR}$ kit (bioMérieux, France) [11]. Data on $\mathrm{mf} / \mathrm{mL}$ from the 20 individuals are available from the corresponding author on reasonable request.

\section{Diagnosis of filarial and STH DNA from stool samples}

To assess the efficacy of the DNA extraction, we ran a PCR targeting a 460-500-bp mitochondrial DNA fragment spanning the human $12 \mathrm{~S}$ rDNA region. Subsequently, to detect the presence of filariae, we ran nested PCRs targeting fragments of two mitochondrial genes (12S rDNA and Cox1), one-step PCRs targeting fragments of the Internal Transcribed Spacer 1 (ITS1), and the LL20 15KDa ladder antigen gene (see Table 1). PCRs were run for DNA extracted from DBS from 20 individuals, for DNA extracted from stools from 52 additional individuals alone, and for DNA extracted from stools from the latter individuals with an addition of $0.1 \mu \mathrm{L}$ of $M$. perstans DNA and $0.05 \mu \mathrm{L}$ of $L$. loa DNA extracted from the DBS positive samples to check for the presence of PCR inhibitors. Negative controls were included to check for contaminations. To validate this protocol in fecal samples, PCRs targeting a fragment of the ITS1 (using primers Mp-Sen-F and Mp-Sen-R) were also run on six DNA samples extracted from chimpanzees positive for Mansonella sp. (for 12S rDNA or Cox1) [6]. To confirm the results of the stool microscopic examinations, nested or seminested PCRs targeting ITS1 or ITS2 fragments of the STH genomes, respectively, were also run (primers, PCR conditions and references listed in Table 1). The sequences were assembled and corrected manually with SeqMan DNAstar (Laser-Gene, DNASTAR, Inc., Madison, WI, USA), then compared to the reference sequences available in GenBank, using the Nucleotide Basic Local Alignment Search Tool (BLASTn).

\section{Results and discussion \\ Detection of M. perstans and L. Ioa}

Six DNA samples extracted from chimpanzee feces were positive for Mansonella sp., using primers MP-Sen targeting the ITS1, confirming previous results [6]. Although the detection of human DNA is not a guarantee that pathogen DNA has not been degraded, it was successfully amplified in all 52 stool samples. An RT-qPCR inhibition screening test was 
Table 1. Primers list, PCR conditions, and references.

\begin{tabular}{|c|c|c|c|c|c|c|c|c|c|c|c|c|}
\hline \multirow[t]{3}{*}{ Host target } & \multirow[t]{3}{*}{ Gene } & \multicolumn{3}{|c|}{ Primer } & \multicolumn{7}{|c|}{ Thermal profile $^{\mathrm{a}}$} & \multirow[t]{3}{*}{ Ref. } \\
\hline & & \multirow[t]{2}{*}{ Designation } & \multirow[t]{2}{*}{ Sequence $\left(5^{\prime}-3^{\prime}\right)$} & \multirow{2}{*}{$\frac{\text { Product }}{\text { Size (bp) }}$} & \multicolumn{2}{|c|}{ Step 1} & \multirow{2}{*}{$\frac{\text { Step } 2}{T}$} & \multicolumn{3}{|c|}{ Step 3} & \multirow[t]{2}{*}{$N$} & \\
\hline & & & & & $T$ & $D$ & & $D$ & $T$ & $D$ & & \\
\hline \multirow[t]{2}{*}{ Homo sapiens } & HVRI & L15997 & CACCATTAGCACCCAAAGCT & $\sim 400$ & 94 & 30 & 50 & 30 & 72 & 30 & 40 & [17] \\
\hline & & H16498 & CCTGAAGTAGGAACCAGATG & & & & & & & & & \\
\hline \multirow[t]{4}{*}{ L. loa/M. perstans } & $12 S \mathrm{rDNA}$ & 12SdegF2/ & ATTACYTATTYTTAGTTTA & $\sim 600$ & 94 & 30 & 45 & 30 & 72 & 45 & 40 & [2] \\
\hline & & 12SnemR2 & CTACCATACTACAACTTACGC & & & & & & & & & \\
\hline & & $12 \mathrm{SF} /$ & GTTCCAGAATAATCGGCTA & $\sim 450$ & 94 & 30 & 54 & 30 & 72 & 30 & 35 & \\
\hline & & 12SdegR & ATTGACGGATGRTTTGTACC & & & & & & & & & \\
\hline \multirow{4}{*}{ L. loa/M. perstans } & $\operatorname{cox} I$ & FCo1extdF1 & TATAATTCTGTTYTDACTA & $\sim 970$ & 94 & 30 & 44 & 30 & 72 & 60 & 40 & [2] \\
\hline & & FCo1extdR1 & ATGAAAATGAGCYACWACATAA & & & & & & & & & \\
\hline & & COIintF/ & TGA TTG GTG GTT TTG GTA A & $\sim 650$ & 94 & 30 & 45 & 30 & 72 & 45 & 35 & \\
\hline & & COIintR & ATA AGT ACG AGT ATC AAT ATC & & & & & & & & & \\
\hline \multirow{4}{*}{$\begin{array}{l}\text { Oesophagostomum/ } \\
\text { Necator sp. }\end{array}$} & ITS2 & $\mathrm{NC} 1$ & ACGTCTGGTTCAGGGTTGTT & NA & 94 & 30 & 50 & 30 & 72 & 45 & 45 & [7] \\
\hline & & $\mathrm{NC} 2$ & TTAGTTTCTTTTCCTCCGCT & & & & & & & & & \\
\hline & & OesophITS2 & TGTRACACTGTTTGTC-GAAC & $250-300$ & 94 & 30 & 55 & 30 & 72 & 30 & 35 & \\
\hline & & $\mathrm{NC} 2$ & TTAGTTTCTTT-TCCTCCGCT & & & & & & & & & \\
\hline \multirow[t]{4}{*}{ Thrichuris trichiura } & ITS2 & ExtITS2 & GGATCACTTGGCTGGTAG & NA & 94 & 30 & 56 & 30 & 72 & 45 & 45 & [8] \\
\hline & & NC2 & TTAGTTTCTTTTCCTCCGCT & & & & & & & & & \\
\hline & & IntITS2 & CTTGAATACTTTGAACGCACATTG & $\sim 700$ & 94 & 30 & 49 & 30 & 72 & 45 & 35 & \\
\hline & & NC2 & TTAGTTTCTTTTCCTCCGCT & & & & & & & & & \\
\hline \multirow[t]{4}{*}{ Acaris lumbricoides } & ITS1 & ITS F1 & CGAGCAGAAAAAAAAAAGTCTCC & NA & 94 & 30 & 50 & 45 & 72 & 45 & 45 & [3] \\
\hline & & ITS R1 & GGAATGAACCCGATGGCGCAAT & & & & & & & & & \\
\hline & & ITS F2 & CGAGCAGAAAAAAAAAAAAGTCTCC & $\sim 500$ & 94 & 30 & 52 & 30 & 72 & 30 & 35 & \\
\hline & & ITS R2 & GCTGCGTTCTTCATCGAT & & & & & & & & & \\
\hline \multirow[t]{2}{*}{ Mansonella perstans } & ITS1 & Mp-SEN-F & AGGATCATTAACGAGCTTCC & $\sim 187$ & 94 & 30 & 50 & 30 & 72 & 30 & $35^{\mathrm{b}}$ & [1] \\
\hline & & Mp-SEN-R & CGAATATCACCGTTAATTCAGT & & & & & & & & & \\
\hline \multirow[t]{2}{*}{ Loa loa } & LL20 15KDa & $15 \mathrm{r} 3-\mathrm{LL}-\mathrm{F}$ & CGAAAAATTATAGGGGGAAAC & $\sim 148$ & 94 & 30 & 50 & 30 & 72 & 30 & $35^{\mathrm{b}}$ & [15] \\
\hline & & 15r3-LL-R & TCGTAGACCAAACTGCGAAC & & & & & & & & & \\
\hline
\end{tabular}

${ }^{\text {a }}$ All PCRs start at $95{ }^{\circ} \mathrm{C}-15 \mathrm{~min}$ and finish at $72{ }^{\circ} \mathrm{C}-10 \mathrm{~min}$.

b $35 \times$ for DBS and $45 \times$ for stool samples.

NA: not available. In all cases, the PCR reaction was performed in $50 \mu \mathrm{L}$ reaction volume containing $10 \mu \mathrm{L}$ and $5 \mu \mathrm{L}$ of template DNA for primary and nested PCR respectively, $10 \mathrm{pM}$ of each primer, $25 \mu \mathrm{L}$ HotStarTaq Master Mix (Qiagen, Courtaboeuf, France), providing a final concentration of $1.5 \mathrm{mM} \mathrm{MgCl}$ and $200 \mu \mathrm{M}$ each dNTP, $1 \mu \mathrm{g}$ of Bovine Serum Albumin (SIGMA, USA).

Abbreviations: Step 1, denaturation; Step 2, annealing; Step 3, elongation; $T$, temperature $\left({ }^{\circ} \mathrm{C}\right) ; D$, duration (s); $N$, number of cycles.

conducted on a subset of samples by targeting the human albumin gene. No PCR method was able to amplify M. perstans and L. loa target fragments from the DNA extracted. However, samples in which a dilution of DNA extracted from DBS was added were all positive. The same DNA extraction methods were applied for the chimpanzee fecal samples for which we were able to detect the presence of filariae.

\section{Detection of soil-transmitted helminths}

All samples were analyzed for the presence of Necator americanus, Trichuris trichiura, and Ascaris lumbricoides by the Kato-Katz technique, Mini-FLOTAC and conventional PCR (Table 2). Five participants were infected with T. trichiura, four with A. lumbricoides, one with both species, but none with $N$. americanus. Thus, altogether, the number of patients infected with STH was low. These findings corroborate those obtained during a National survey conducted in 2010 [14], which reported low prevalence of infection in school children living in the Centre Region (10.5, 18.6 and $2.7 \%$ for A. lumbricoides, T. trichiura and hookworms, respectively), and those obtained in 2020 in adults living in villages included in the TaNT project mentioned above (prevalence of $1.4 \%$ for A. lumbricoides and $2.2 \%$ for $T$. trichiura) (Nana-Djeunga, unpublished results). This situation probably results from the fact that (a) the health areas neighboring the TaNT villages have been treated with ivermectin for about two decades to fight onchocerciasis; (b) most of the people living in the TaNT villages benefitted from annual treatment with ivermectin between 2015 and 2018 (subjects excluded from this treatment represent less than $3 \%$ of those tested with the LoaScope); and (c) school-aged children of the whole health district have received regular mebendazole treatment since 2007. Of note, it has been shown recently that, in areas where ivermectin is administered as a mass treatment, the impact is greater on STH transmission compared to where only mebendazole has been administered [4]. Given the absence of hookworm infection, the low proportion of participants infected with T. trichiura or A. lumbricoides, and the low egg counts recorded (Table 2), STH-related blood loss in the intestine was probably minimal. This may explain the absence of DNA from blood-dwelling $\mathrm{mf}$ in the samples examined. Importantly, among the six chimpanzee stool samples that we found to be positive for Mansonella sp., five were infected with Oesophagostomum sp. and/or Necator sp. [6]. 
Table 2. CTBS results for L. loa and M. perstans and Kato-Katz, Mini-FLOTAC and PCR results for soil-transmitted helminths.

\begin{tabular}{|c|c|c|c|c|c|c|c|c|}
\hline $\begin{array}{l}\text { No. stool } \\
\text { sample }\end{array}$ & $\begin{array}{l}\text { Giemsa staining } \\
\text { M. perstans } \\
(\mathrm{mf} / \mathrm{mL})\end{array}$ & $\begin{array}{c}\text { Giemsa staining } \\
\text { of } L . \text { loa } \\
(\mathrm{mf} / \mathrm{mL})\end{array}$ & $\begin{array}{c}\text { T. trichiura egg } \\
\text { count/Kato-Katz } \\
\text { (epg) }\end{array}$ & $\begin{array}{l}\text { T. trichiura egg } \\
\text { count/mini } \\
\text { FLOTAC }\end{array}$ & $\begin{array}{l}\text { PCR ITS2 } \\
\text { T. trichiura }\end{array}$ & $\begin{array}{l}\text { A. lumbricoides } \\
\text { egg count/ } \\
\text { Kato-Katz (epg) }\end{array}$ & $\begin{array}{l}\text { A. lumbricoides } \\
\text { egg count/mini } \\
\text { FLOTAC }\end{array}$ & $\begin{array}{l}\text { PCR ITS1 } \\
\text { A. lumbricoides } \\
\end{array}$ \\
\hline S-001 & 1340 & 57,140 & 0 & 0 & NEG & 48 & 0 & NEG \\
\hline S-002 & 240 & 35,260 & 0 & 0 & NEG & 0 & 20 & NEG \\
\hline S-003 & 0 & 29,280 & 0 & 0 & NEG & 0 & 0 & NEG \\
\hline S-004 & 0 & 65,740 & 0 & 0 & NEG & 0 & 0 & NEG \\
\hline S-005 & 0 & 71,500 & 0 & 0 & NEG & 0 & 0 & NEG \\
\hline S-006 & 0 & 47,380 & 0 & 0 & NEG & 0 & 0 & NEG \\
\hline S-007 & 0 & 18,840 & 0 & 0 & NEG & 0 & 0 & NEG \\
\hline S-008 & 0 & 23,200 & 0 & 0 & NEG & 0 & 0 & NEG \\
\hline S-009 & 0 & 92,000 & 0 & 0 & NEG & 0 & 0 & NEG \\
\hline S-010 & 0 & 51,040 & 0 & 15 & POS & 0 & 0 & NEG \\
\hline S-011 & 0 & 58,640 & 0 & 0 & NEG & 0 & 0 & NEG \\
\hline S-012 & 0 & 17,260 & 0 & 0 & NEG & 0 & 0 & NEG \\
\hline S-013 & 20 & 3300 & 0 & 0 & NEG & 0 & 0 & NEG \\
\hline S-014 & 0 & 35,780 & 0 & 0 & NEG & 0 & 0 & NEG \\
\hline S-015 & 0 & 223,700 & 0 & 0 & NEG & 0 & 0 & NEG \\
\hline S-016 & 80 & 46,760 & 0 & 0 & NEG & 0 & 0 & NEG \\
\hline S-017 & 100 & 10,300 & 0 & 0 & NEG & 0 & 0 & NEG \\
\hline S-018 & 160 & 28,520 & 0 & 0 & NEG & 0 & 0 & NEG \\
\hline S-019 & 0 & 13,740 & 0 & 0 & NEG & 0 & 5 & NEG \\
\hline S-020 & 0 & 1960 & 0 & 5 & NEG & 0 & 0 & NEG \\
\hline S-021 & 0 & 29,200 & 0 & 0 & NEG & 0 & 0 & NEG \\
\hline S-022 & 0 & 45,560 & 0 & 0 & NEG & 0 & 0 & NEG \\
\hline S-023 & 0 & 137,180 & ND & ND & NEG & ND & ND & NEG \\
\hline S-024 & 660 & 24,920 & 0 & 0 & NEG & 0 & 0 & NEG \\
\hline S-025 & 140 & 20,180 & 0 & 0 & NEG & 0 & 0 & NEG \\
\hline S-026 & 0 & 19,060 & 0 & 0 & NEG & 0 & 0 & NEG \\
\hline S-027 & 0 & 4480 & 0 & 0 & NEG & 0 & 0 & NEG \\
\hline S-028 & 0 & 41,380 & 0 & 0 & NEG & 0 & 0 & NEG \\
\hline S-029 & 0 & 5000 & 0 & 0 & NEG & 0 & 0 & NEG \\
\hline S-030 & 0 & 66,400 & 0 & 0 & NEG & 0 & 0 & NEG \\
\hline S-031 & 200 & 25,640 & 0 & 0 & NEG & 0 & 0 & NEG \\
\hline S-032 & 20 & 46,720 & 0 & 0 & NEG & 0 & 0 & NEG \\
\hline S-033 & 420 & 41,180 & 24 & 15 & NEG & 8088 & 3700 & POS \\
\hline S-034 & 0 & 45,500 & 0 & 0 & NEG & 0 & 0 & NEG \\
\hline S-035 & 360 & 8600 & ND & ND & NEG & ND & ND & NEG \\
\hline S-037 & 240 & 7500 & 0 & ND & NEG & 0 & ND & NEG \\
\hline S-038 & 0 & 22,900 & 0 & 0 & NEG & 0 & 0 & NEG \\
\hline S-039 & 0 & 8840 & 0 & 0 & NEG & 0 & 0 & NEG \\
\hline S-040 & 0 & 8000 & 0 & 5 & NEG & 0 & 0 & NEG \\
\hline S-041 & 0 & 18,700 & 0 & 0 & NEG & 0 & 0 & NEG \\
\hline S-042 & 0 & 27,760 & 0 & 0 & NEG & 0 & 0 & NEG \\
\hline S-043 & 140 & 72,920 & 0 & 0 & NEG & 0 & 0 & NEG \\
\hline S-044 & 0 & 51,820 & 0 & 0 & NEG & 0 & 0 & NEG \\
\hline S-045 & 0 & 1800 & 0 & 0 & NEG & 0 & 0 & NEG \\
\hline S-046 & 0 & 25,680 & 0 & 0 & NEG & 0 & 5 & NEG \\
\hline S-047 & 0 & 72,500 & 0 & 0 & ND & 0 & 0 & NEG \\
\hline S-048 & 0 & 2960 & 0 & 0 & NEG & 0 & 0 & NEG \\
\hline S-049 & 0 & 30,600 & 0 & 5 & NEG & 0 & 0 & NEG \\
\hline S-050 & 0 & ND & 0 & 0 & NEG & 0 & 0 & NEG \\
\hline S-051 & ND & ND & 0 & 5 & NEG & 0 & 0 & NEG \\
\hline S-052 & ND & ND & 0 & 0 & NEG & 0 & 0 & NEG \\
\hline
\end{tabular}

(1) PCR 12S rDNA (human mitochondrial DNA): all positive. (2) PCR 12S rDNA (filariae): all negative. (3) PCR cox1 (filariae): all negative. (4) PCR ITS1 M. perstans: all negative. (5) PCR ITS1 $M$. perstans-inhibition test (0.1 $\mu$ L DBS DNA): all positivePCR $L$. loa LL20-15kDA: all negative. (6) PCR L. loa LL20-15kDA-inhibition test (0.05 $\mu$ L DBS DNA): all positive. (7) Hookworm egg count/Kato-Katz (epg)/mini FLOTAC/PCR ITS2 N. americanus/Oesophagostomum spp. (8) ND: not determined.

\section{Conclusion}

We obtained PCR-negative results for the detection of filarial DNA in human feces from infected patients. RT-qPCR may display higher sensitivity compared to conventional PCR, and this may be the limitation of this study. However, filarial DNA detection appears to work better in NHPs co-infected with intestinal parasites. If co-infection with intestinal parasites 
is necessary, then the present study clearly suffered from a lack of statistical power. We had assumed that a significant proportion of subjects would be infected with STH, but this was not the case. Further studies should target individuals co-infected with STH (especially hookworms) and filariae to test our hypothesis. It should be noted that gastrointestinal bleeding may also be caused by other diseases such as colon cancer, hemorrhoids or ulcerations, and therefore a fecal occult blood test could complement the search for STH. In addition, exploring the presence in fecal samples of cell-free DNA (cfDNA) fragments from various pathogens is an approach worth investigating in the future [18]. The development of a reliable, non-invasive test combining the detection of different parasites in one sample could be useful when samples are collected in remote regions with difficult access to points of care $[13,16]$.

\section{Availability of data and materials}

Datasets and questionnaires are available from the corresponding author under reasonable request.

\section{Authors' contributions}

Study design: HCND, SDSP, CBC, SL. Data collection and microscopic analyses: HCND, NNT. PCR experiments: MPMD, SL. Data analysis: MPMD, HCND, SL. Writing: MPMD, SL with input from all authors. All authors read and approved the final manuscript.

\section{Conflict of interest}

The authors declare that they have no conflict of interest.

Acknowledgements. The authors are grateful to the patients from the Okola Health District enrolled in this study, to Floribert Fossuo-Thotchum, Arnauld Efon-Ekangouo, Aubin Yves Balog and Jean Bopda for technical assistance at CRFilMT in Yaoundé, to Colette Gaillard, Thomas Lemarcis, Christelle Butel and Laetitia Serrano for technical assistance at IRD. We thank Patrick Bastien for scientific support. This work was supported by a MsC-Biomarkers \& Therapy grant 2018-2019 from the Montpellier University of Excellence (MUSE).

\section{References}

1. Bassene H, Sambou M, Fenollar F, Clarke S, Djiba S, Mourembou G, Alioune Badara LY, Raoult D, Mediannikov O. 2015. High prevalence of Mansonella perstans filariasis in rural Senegal. American Journal of Tropical Medecine \& Hygiene, 93(3), 601-606.

2. Casiraghi M, Anderson TJ, Bandi C, Bazzocchi C, Genchi C. 2001. A phylogenetic analysis of filarial nematodes: comparison with the phylogeny of Wolbachia endosymbionts. Parasitology, 122 Pt 1, 93-103.

3. Das K, Chowdhury P, Ganguly S. 2015. Internal Transcribed Spacer 1 (ITS1) based sequence typing reveals phylogenetically distinct Ascaris population. Computational and Structural Biotechnology Journal, 13, 478-483.
4. Djune-Yemeli L, Nana-Djeunga HC, Lenou-Nanga CG, DonfoAzafack C, Domche A, Fossuo-Thotchum F, Niamsi-Emalio Y, Ntoumi F, Kamgno J. 2020. Serious limitations of the current strategy to control soil-transmitted helminths and added value of ivermectin/albendazole mass administration: a population-based observational study in Cameroon. PLoS Neglected Tropical Diseases, 14(11), e0008794.

5. Fischer P, Boakye D, Hamburger J. 2003. Polymerase chain reaction-based detection of lymphatic filariasis. Medical Microbiology and Immunology, 192(1), 3-7.

6. Gaillard CM, Pion SD, Hamou H, Sirima C, Bizet C, Lemarcis T, Rodrigues J, Esteban A, Peeters M, Mpoudi Ngole E, Mombo I, Liegeois F, Martin C, Boussinesq M, Locatelli S. 2020. Detection of DNA of filariae closely related to Mansonella perstans in faecal samples from wild non-human primates from Cameroon and Gabon. Parasites \& Vectors, 13(1), 313.

7. Ghai RR, Chapman CA, Omeja PA, Davies TJ, Goldberg TL. 2014. Nodule worm infection in humans and wild primates in Uganda: cryptic species in a newly identified region of human transmission. PLoS Neglected Tropical Diseases, 8(1), e2641.

8. Ghai RR, Simons ND, Chapman CA, Omeja PA, Davies TJ, Ting N, Goldberg TL. 2014. Hidden population structure and cross-species transmission of whipworms (Trichuris sp.) in humans and non-human primates in Uganda. PLoS Neglected Tropical Diseases, 8(10), e3256.

9. Kamgno J, Pion SD, Chesnais CB, Bakalar MH, D'Ambrosio MV, Mackenzie CD, Nana-Djeunga HC, GounoueKamkumo R, Njitchouang GR, Nwane P, Tchatchueng-Mbouga JB, Wanji S, Stolk WA, Fletcher DA, Klion AD, Nutman TB, Boussinesq M. 2017. A test-and-not-treat strategy for onchocerciasis in Loa loa-endemic areas. New England Journal of Medicine, 377(21), 2044-2052.

10. Lagatie O, Merino M, Batsa Debrah L, Debrah AY, Stuyver LJ. 2016. An isothermal DNA amplification method for detection of Onchocerca volvulus infection in skin biopsies. Parasites \& Vectors, 9(1), 624.

11. Monleau M, Aghokeng AF, Eymard-Duvernay S, Dagnra A, Kania D, Ngo-Giang-Huong N, Toure-Kane C, Truong LX, Chaix ML, Delaporte E, Ayouba A, Peeters M, Group AS. 2014. Field evaluation of dried blood spots for routine HIV-1 viral load and drug resistance monitoring in patients receiving antiretroviral therapy in Africa and Asia. Journal of Clinical Microbiology, 52(2), 578-586.

12. Poole CB, Tanner NA, Zhang Y, Evans TC Jr, Carlow CK. 2012. Diagnosis of brugian filariasis by loop-mediated isothermal amplification. PLoS Neglected Tropical Diseases, 6(12), e1948.

13. Priest JW, Jenks MH, Moss DM, Mao B, Buth S, Wannemuehler K, Soeung SC, Lucchi NW, Udhayakumar V, Gregory CJ, Huy R, Muth S, Lammie PJ. 2016. Integration of multiplex bead assays for parasitic diseases into a national, population-based serosurvey of women 15-39 years of age in Cambodia. PLoS Neglected Tropical Diseases, 10(5), e0004699.

14. Tchuem Tchuente LA, Kamwa Ngassam RI, Sumo L, Ngassam P, Dongmo Noumedem C, Nzu DD, Dankoni E, Kenfack CM, Gipwe NF, Akame J, Tarini A, Zhang Y, Angwafo FF 3rd. 2012. Mapping of schistosomiasis and soil-transmitted helminthiasis in the regions of centre, East and West Cameroon. PLoS Neglected Tropical Diseases, 6(3), e1553.

15. Toure FS, Bain O, Nerrienet E, Millet P, Wahl G, Toure Y, Doumbo O, Nicolas L, Georges AJ, McReynolds LA, Egwang TG. 1997. Detection of Loa loa-specific DNA in blood from occultinfected individuals. Experimental Parasitology, 86(3), 163-170.

16. Utzinger J, Becker SL, Knopp S, Blum J, Neumayr AL, Keiser J, Hatz CF. 2012. Neglected tropical diseases: diagnosis, clinical management, treatment and control. Swiss Medical Weekly, 142, w13727. 
17. van der Kuyl AC, Kuiken CL, Dekker JT, Goudsmit J. 1995. Phylogeny of African monkeys based upon mitochondrial $12 \mathrm{~S}$ rRNA sequences. Journal of Molecular Evolution, 40(2), 173-180.
18. Weerakoon KG, McManus DP. 2016. Cell-free DNA as a diagnostic tool for human parasitic infections. Trends in Parasitology, 32(5), 378-391.

Cite this article as: Doret MPM, Nana-Djeunga HC, Nzune-Toche N, Pion SDS, Chesnais CB, Boussinesq M, Kamgno J, Varlet-Marie E \& Locatelli S. 2021. Limitations of PCR detection of filarial DNA in human stools from subjects non-infected with soil-transmitted helminths. Parasite 28, 47.

\section{O PARASTE}

An international open-access, peer-reviewed, online journal publishing high quality papers on all aspects of human and animal parasitology

Reviews, articles and short notes may be submitted. Fields include, but are not limited to: general, medical and veterinary parasitology; morphology, including ultrastructure; parasite systematics, including entomology, acarology, helminthology and protistology, and molecular analyses; molecular biology and biochemistry; immunology of parasitic diseases; host-parasite relationships; ecology and life history of parasites; epidemiology; therapeutics; new diagnostic tools.

All papers in Parasite are published in English. Manuscripts should have a broad interest and must not have been published or submitted elsewhere. No limit is imposed on the length of manuscripts.

Parasite (open-access) continues Parasite (print and online editions, 1994-2012) and Annales de Parasitologie Humaine et Comparée (1923-1993) and is the official journal of the Société Française de Parasitologie. 